\title{
PLASMA TRYPTOPHAN TOLERANCE CURVES IN DRUG FREE NORMAL CONTROLS, SCHIZOPHRENIC PATIENTS AND PRISONER VOLUNTEERS*
}

\author{
Edward F. Domino and Rachel R. Krause \\ Michigan Neuropsychopharmacology Research Program, \\ Laboratory of Pharmacology, Lafayette Clinic, Detroit, Michigan 48207, and \\ University of Michigan, Ann Arbor, Michigan 48104, U.S.A.
}

(Received 18 January 1973; in revised form 6 September 1973)

\section{INTRODUCTION}

A DISTURBANCE in indole metabolism, particularly 5-hydroxytryptamine (5-HT) and its metabolites, has been proposed in various psychiatric disorders. These include schizophrenia $^{1-6}$ and mental depression. ${ }^{7-9}$ Large oral tryptophan (TP) loads given with a monoamine oxidase inhibitor exacerbate some of the symptoms of schizophrenics but also produce central nervous system effects in non-psychotic patients. ${ }^{10-13}$ TP has also been used in the treatment of depression. ${ }^{14-15}$

In view of the fact that the primary source of brain indoles is ultimately TP, it was important to establish that fasting plasma levels of TP and those following oral loads were within normal limits in psychiatric patients. Fernstrom and Wurtman ${ }^{16}$ have shown that rat brain 5-HT levels are related to plasma TP. They have also shown that the ratio of TP to other plasma neutral amino acids such as tyrosine, phenylalanine, leucine, isoleucine and valine regulate brain TP and hence brain 5-HT. ${ }^{17}$

In the present study venous blood samples from four different diagnostic groups were analyzed for plasma TP. The subjects were drug free chronic schizophrenics, acute schizophrenics, prisoner volunteers with personality disorders with and without depression, and normals consisting of staff personnel and medical students. This manuscript describes the changes in total plasma TP in these subjects before and after a $32 \mathrm{mg} / \mathrm{kg}$ oral TP load given in the morning and a standard meal containing $394.4 \mathrm{mg}$ of TP and 1187 calories given in the evening.

\section{METHODS}

\section{Schizophrenic patient population}

The chronic patients were 28 adult males, drug free for at least 6-8 months prior to the study. Because of discharge from the research ward for multiple reasons, smaller numbers were actually studied on different parameters. All patients were diagnosed as chronic schizophrenics independently by three to five psychiatrists and came from various state

* Supported in part by Grant MH-11846 and Special Fellowship 1 FO3 GM 54874 (to EFD), United States Public Health Service. Presented in part in abstract form before the Society of Biological Psychiatry Meetings in Montreal, Canada, June, 1973. 
hospitals in Michigan, primarily Northville State Hospital. Patients were selected on the basis of chronicity, failure to respond to antipsychotic drug therapy, absence of physical or neurological disease, and process schizophrenia. All of the patients had Bleuler's primary symptoms of schizophrenia including (a) thought disorder (b) disturbance of association (c) autistic behavior and (d) altered affect. The patients were from 24 to $46 \mathrm{yr}$ of age and were predominantly Caucasian. Absence of neurological and physical disease was determined on the basis of history, physical examination, clinical laboratory tests and EEG recordings. The patients were transferred from the state hospitals to the Lafayette Clinic research ward. If they were on medication it was abruptly withdrawn shortly after admission. Supportive recreational therapy including adequate exercise was initiated. Patients were given a 2300 calorie per day diet with vitamin supplements (one Myadec/day) for at least 4 months prior to the study. Each patient was the subject of simultaneous psychological, physiological and biochemical studies carried out by other investigators at the Clinic. These studies involved plasmapheresis and withdrawal of blood. Patients subjected to plasmapheresis were not used as subjects for at least one month after this procedure. All chronic schizophrenic patients were additionally subdivided on the basis of presence, absence or loss of an $\alpha$-2-globulin protein fraction as described by Frohman ${ }^{2}$ and Gottlieb et $a l^{3}$ These patients will be referred to as $S$-protein $\alpha$ helical (group A) or $S$-protein nonhelical (group B). A group C consisted of former group A patients in whom, at the time of the present study, $S$-protein $\alpha$ helical was no longer measurable. The patients were classified by Dr. Frohman on the basis of TP uptakes done on varying occasions within a 6 month period using criteria previously published. ${ }^{2,3}$

\section{Prisoner volunteer population}

The subjects were 24 male volunteers, free of drugs for at least one month prior to study. They were all inmates of the State Prison of Southern Michigan. All were part of a larger screened pool of prisoner volunteers for Phase 1 drug studies, usually carried on in the Parke Davis \& Company and/or the Upjohn Company facilities at this institution. Approximately 50 such volunteers were then given an elaborate physical examination and clinical laboratory tests to exclude neurological and physical disease. In addition, a brief psychiatric interview and the self-administered MMPI was used to further assist in a psychiatric diagnosis. The prisoner population was characterized as predominately having personality disorders with definite tendencies to symptoms of depression and/or psychosis on the basis of the MMPI.18 Two clinical psychologists were independently asked to rate the prisoners as moderately or mildly depressed, severely psychotic or having a character disorder. Only prisoners rated by both as depressed, with or without character disorder, were compared to those rated as normal or having a character disorder. A total of 24 prisoners was selected from a much larger pool of subjects. Each prisoner was given a multivitamin capsule (Myadec) every morning for one week prior to his participation in the study.

\section{Control population}

Adult males with a normal medical history and psychiatric status were selected from medical students and Lafayette Clinic personnel to form a control group. All fasted overnight prior to the morning of the test and were drug free for one to two months prior to the 
cxperiment. Acctylsalicylic acid and alcoholic beverages were allowed on rare occasions but never during the 24-hr period immediately preceding blood withdrawal. All subjects were instructed to go about their usual daily activities. The control group probably had less exercise than the schizophrenic patients who exercised regularly. An attempt was made to match controls and patients for height, weight and age. The patients tended to be underweight, therefore, grossly overweight controls were excluded. The control group ranged in age from 19 to $53 \mathrm{yr}$.

\section{Clinical chemistry}

Standard clinical blood and urine tests were carried out on the chronic schizophrenic patients and prisoner volunteers. These included hemoglobin, hematocrit, red and white blood cell count, serum calcium, inorganic phosphate, glucose, blood urea nitrogen, uric acid, cholesterol, total protein, bilirubin, alkaline phosphatase, LDH, SGOT, SGPT and creatinine. Urinalysis included a gross and microscopic examination, specific gravity, glucose and protein.

\section{Tryptophan source and assay}

L-tryptophan (TP) was obtained from General Biochemicals Inc. and was prepared in $2 \mathrm{~g}$ packets by the University of Michigan Hospital Pharmacy. The night before the oral TP load the patient or subject was weighed; $32 \mathrm{TP} \mathrm{mg} / \mathrm{kg}$ of body wt was mixed with $2 \mathrm{oz}$ apple sauce, 1 tablespoon sucrose and 3 drops lemon flavoring. The subjects were asked to eat the mixture as fast as possible. Two additional oz of apple sauce also were given to make sure all of the TP was ingested. Fasting venous blood samples were taken before TP administration at approximately 7:30 a.m. and further samples were taken $\frac{1}{2}, 1,2,4$ and $7 \mathrm{hr}$ after ingestion. In general, all meals were withheld until after the last blood sample although occasional subjects obtained a 12:00 noon lunch. Small lunches taken by mistake did not seem to affect the TP plasma tolerance curve. Subjects were allowed to smoke tobacco cigarettes and drink coffee but were discouraged from that use during the morning by substitution of lettuce cigarettes and decaffeinated coffee. In addition to a morning fasting sample, the schizophrenic patients were subjected to an evening fast at a later date in which a light lunch was served at 12:00 noon and no additional food given until 8:30 p.m. when a blood sample was taken. Plasma TP was determined at that time as well as several months earlier when the schizophrenic patients and prisoner volunteers were served a standard meal which included a $3 \mathrm{oz}$ turkey foldover with $2 \mathrm{oz}$ gravy, $4 \mathrm{oz}$ cauliflower, $2 \mathrm{oz}$ tossed salad consisting of lettuce, celery, tomatoes and cucumber with $1 \mathrm{oz}$ oil and $1 \mathrm{oz}$ vinegar dressing, 1 slice bread, $\frac{1}{6}$ of an 8 in. apple pie weighing $5 \cdot 5 \mathrm{oz}, 8 \mathrm{oz}$ cold milk and $8 \mathrm{oz}$ Meritine (a dietary supplement). This meal contained approximately 1187 calories and $394.4 \mathrm{mg}$ of TP. ${ }^{19}$

Total plasma TP was determined by the method of Denckla and Dewey. ${ }^{(20)}$ This method is based upon the condensation of formaldehyde with TP to form the fluorophor norharman. Twenty $\mu 1$ plasma samples were deproteinized with $10 \%$ trichloroacetic acid containing $3 \times 10^{-4} \mathrm{M} \mathrm{FeCl}_{3}$. The supernatant was incubated with formaldehyde for $1 \mathrm{hr}$ at $99^{-}$ $101^{\circ} \mathrm{C}$. Samples and standards were read in a Farrand Mark I spectrophotofluorometer at an excitation and analyzing wavelength of 373 and $452 \mathrm{~nm}$, respectively. TP standard was obtained from Aldrich Chemical Company. All blood samples were heparinized (4 U 
heparin/ml of blood). Samples were immediatcly centrifuged and the plasma removed and frozen at $-10^{\circ} \mathrm{C}$ for assay, usually the next day. Frozen plasma samples were always assayed within one week of being drawn.

\section{Statistical analysis}

Computations were carried out using the Olivetti Programma 101 statistical programs. ${ }^{21}$ These included paired and group comparison Student $t$-tests. ${ }^{22}$ The following TP parameters were measured: fasting, peak level, largest changes in $\mathrm{TP}$ ( $\Delta \mathrm{TP}=$ peak-fasting), time of peak TP, 2-4 hr slope of decreasing TP, 4-7 hr slope of decreasing TP, actual measured area under the curve of plasma TP at $0-7,0-1$ and $1-7 \mathrm{hr}$, and normalized area using peak TP as 100 per cent for $0-7,0-1$ and 1-7 hr. Half-life of plasma TP was determined on a semi-logarithmic graphic plot, calculating the time at which half of the peak plasma TP was reached extrapolating to zero time. In addition a complete analysis of TP half life was also performed.

\section{RESULTS}

\section{Effects of fasting and loading on plasma TP}

Plasma TP tolerance curves were determined for normal subjects, chronic schizophrenic patients, and prisoner volunteers. The prisoners were divided into two groups: blood samples drawn at 6:30-7:00 (group 1-12) and 7:30-8:00 a.m. (group 13-24) after an overnight fast and a $32 \mathrm{mg} / \mathrm{kg}$ oral TP load. Plasma samples were taken at the times described earlier. The data of all groups are plotted in Fig. 1 and given in Table 1. It can be noted that the mean $\pm S$.E. fasting plasma TP varied from a low of $10.9 \pm 0.4$ to a high of $16.4 \pm 0.9 \mu \mathrm{g} / \mathrm{ml}$ among the various groups. The mean \pm S.E. of plasma TP for our normal group of 36 subjects (Table 2) was $14.2 \pm 0.5 \mu \mathrm{g} / \mathrm{ml}$. Denckla and Dewey ${ }^{20}$ report a mean \pm S.D. of $11.0 \pm 1.3 \mu \mathrm{g} / \mathrm{ml}$ of plasma TP taken from fingertip blood. Various other investigators have reported normal plasma TP values varying over a wide range depending on the method of assay. Documenta Geigy ${ }^{23}$ lists a plasma or serum TP mean \pm S.D. of $10 \cdot 8 \pm 2 \cdot 1 \mu \mathrm{g} / \mathrm{ml}$. Adibi ${ }^{24}$ reports a mean \pm S.D. of $8.2 \pm 1 \cdot 8$, Perry and Hansen ${ }^{25}$ $6 \cdot 3 \pm 1 \cdot 2$, Gibbs et al. ${ }^{26} 20 \cdot 1 \pm 5 \cdot 3$ and Bio-Science Labs $^{27}$ a mean of $14 \cdot 3 \mu \mathrm{g} / \mathrm{ml}$. Most investigators agree that a plasma or serum TP value of $10-20 \mu \mathrm{g} / \mathrm{ml}$ is within the normal range except for Adibi ${ }^{24}$ and Perry and Hansen. ${ }^{25}$ Thus, the fasting values of plasma TP for all of our subjects and patients fall within the broad range of normal.

There were no significant differences in either fasting or post-TP load values between the mentally normal and either all schizophrenics or schizophrenic subgroups $A, B$ and $C$. There was a significant difference in fasting plasma TP between the first 12 prisoner volunteers (whose samples were taken $1 \mathrm{hr}$ earlier) and the last 12 volunteers $(p<0.01)$, although the latter group had a fasting plasma TP similar to the normal controls. Comparisons of post-load values between the two prisoner subgroups revealed only that at $7 \mathrm{hr}$ subgroup 1-12 had a lower mean plasma TP level than subgroup 13-24, but this difference was barely significant ( $p=0.0548$ for two-tailed $t$-test, $p=0.0274$ for one-tailed $t$-test). The differences in the plasma $T P$ tolerance curves between the two groups of prisoner volunteers were quite surprising for the prisoners originally had been randomly assigned to each group. An additional difference between the normals, chronic schizophrenic patients 


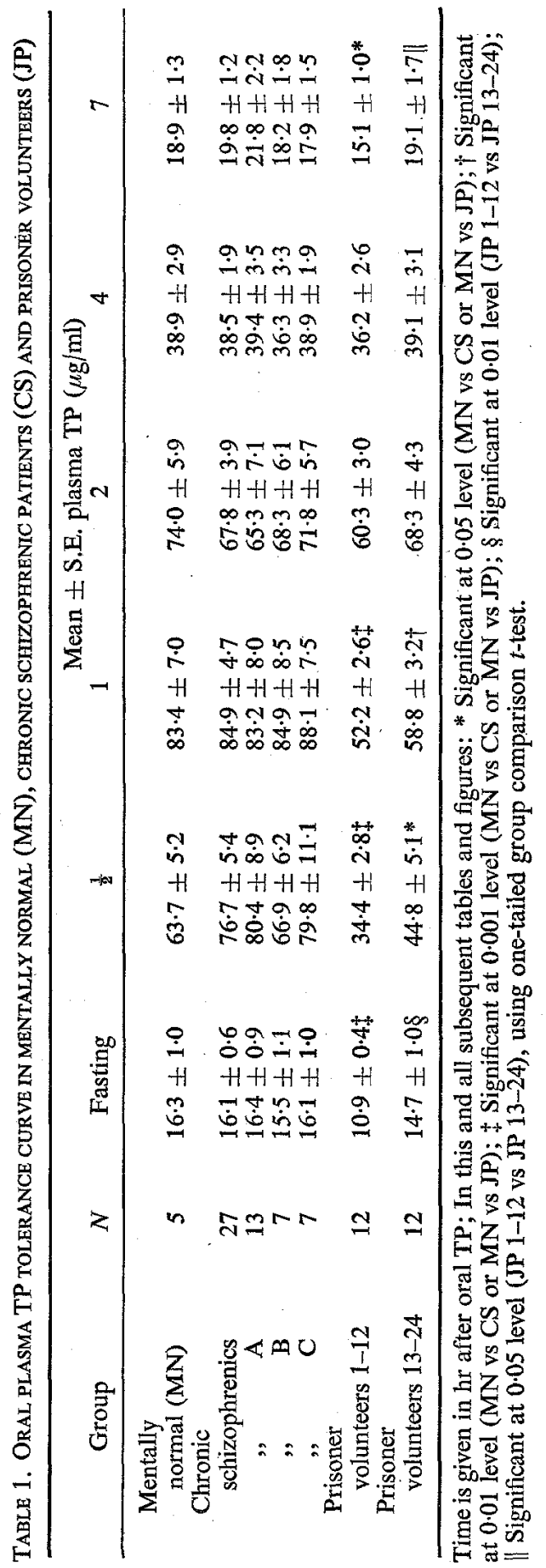


TABle 2. Mean plasma TP parameters Following a $32 \mathrm{mg} / \mathrm{kg}$ ORAL LOAD

\begin{tabular}{|c|c|c|c|c|c|c|}
\hline \multirow[b]{2}{*}{ Parameter } & \multirow[b]{2}{*}{$N$} & \multirow[t]{2}{*}{$\begin{array}{c}\text { Mentally } \\
\text { normal (MN) }\end{array}$} & \multicolumn{3}{|c|}{$\begin{array}{c}\text { Chronic } \\
\text { schizophrenics (CS) }\end{array}$} & \multirow[t]{2}{*}{$\begin{array}{c}\text { Prisoner } \\
\text { volunteers (JP) }\end{array}$} \\
\hline & & & $N$ & & $N$ & \\
\hline $\begin{array}{l}\text { Fasting } \\
\qquad \mu \mathrm{g} / \mathrm{ml}\end{array}$ & 36 & $14 \cdot 2 \pm 0 \cdot 5$ & 27 & $16 \cdot 1 \pm 0.6^{*}$ & 12 & $14 \cdot 7+1 \cdot 0$ \\
\hline $\begin{array}{l}\text { Peak TP } \\
\mu \mathrm{g} / \mathrm{ml}\end{array}$ & 5 & $87 \cdot 9 \pm 4 \cdot 6$ & 27 & $91 \cdot 4 \pm 4 \cdot 6$ & 12 & $71 \cdot 2 \pm 3 \cdot 8^{*}$ \\
\hline $\begin{array}{l}\Delta \mathrm{TP} \text { (peak minus fasting) } \\
\mu \mathrm{g} / \mathrm{ml} \\
\text { Time of neak }\end{array}$ & 5 & $71 \cdot 7 \pm 5 \cdot 3$ & 27 & $75 \cdot 6 \pm 4 \cdot 2$ & 12 & $56 \cdot 5 \pm 3 \cdot 6^{*}$ \\
\hline $\begin{array}{l}\text { Time of peak } \\
\text { hr } \\
\text { Slope, }(2-4 \mathrm{hr})\end{array}$ & 5 & $1 \cdot 2 \pm 0.2$ & 27 & $0.9 \doteqdot 0.1$ & 12 & $1 \cdot 7 \pm 0 \cdot 2$ \\
\hline & 5 & $-17 \cdot 5 \pm 2 \cdot 3$ & 27 & $-14 \cdot 6 \pm 1 \cdot 3$ & 12 & $-14 \cdot 6 \pm 1 \cdot 6$ \\
\hline & 5 & $-6 \cdot 6 \pm 0.7$ & 27 & $-6 \cdot 2 \pm 0 \cdot 4$ & 12 & $-6 \cdot 7 \pm 0 \cdot 6$ \\
\hline $\begin{array}{l}\mu \mathrm{g} \times \mathrm{hr} / \mathrm{ml} \\
\text { Normalized area }(0-1)\end{array}$ & 5 & $40 \cdot 5 \pm 4 \cdot 8$ & 27 & $47 \cdot 3 \pm 3 \cdot 1$ & 12 & $26 \cdot 1 \pm 3 \cdot 4^{*}$ \\
\hline $\begin{array}{l}\mu \mathrm{g} \times \mathrm{hr} / \mathrm{ml} \\
\text { Measured area }(1-7 \mathrm{hr})\end{array}$ & 5 & $48 \cdot 2 \pm 2 \cdot 4$ & 27 & $56 \cdot 9 \pm 2 \cdot 7$ & 12 & $43 \cdot 4 \pm 4 \cdot 6$ \\
\hline $\begin{array}{l}\mu \mathrm{g} \times \mathrm{hr} / \mathrm{ml} \\
\text { Normalized area }(1-7 \mathrm{hr})\end{array}$ & 5 & $179 \cdot 1 \pm 14 \cdot 7$ & 27 & $173 \cdot 6 \pm 11 \cdot 0$ & 12 & $169 \cdot 8 \pm 12 \cdot 1$ \\
\hline $\begin{array}{l}\mu \mathrm{g} \times \mathrm{hr} / \mathrm{ml} \\
\text { Measured area }(0-7 \mathrm{hr})\end{array}$ & 5 & $219 \cdot 9 \pm 24 \cdot 8$ & 27 & $208 \cdot 3 \pm 9 \cdot 7$ & 12 & $293 \cdot 1 \pm 20 \cdot 7$ \\
\hline $\begin{array}{l}\mu \mathrm{g} \times \mathrm{hr} / \mathrm{ml} \\
\text { Normalized area }(0-7 \mathrm{hr})\end{array}$ & 5 & $219 \cdot 7 \pm 16 \cdot 1$ & 27 & $220 \cdot 9 \pm 12 \cdot 5$ & 12 & $195 \cdot 9 \pm 13 \cdot 4$ \\
\hline Normalized area $(U-/ \mathrm{hr})$ & 5 & $268 \cdot 1 \pm 23 \cdot 7$ & 27 & $264 \cdot 8 \pm 9 \cdot 1$ & 12 & $336 \cdot 5 \pm 20 \cdot 5$ \\
\hline $\begin{array}{l}\text { Plasma half-life } \\
\text { hr }\end{array}$ & 5 & $2 \cdot 1 \pm 0.2$ & 27 & $2 \cdot 5 \pm 0 \cdot 1$ & 12 & $2 \cdot 9 \pm 0 \cdot 3^{*}$ \\
\hline
\end{tabular}

and the prisoner volunteers was that the latter tended to lie in bed much more throughout the experiment in contrast to the normals and schizoplurenic patients who usually sat up.

Plasma TP in acute schizophrenics and in chlorpromazine-treated chronic schizophrenics

Values for five drug free acute schizophrenic patients are given in Fig. 2. Plasma TP in this group was much lower than in the normals $(p<0.001)$. Plasma TP was measured before and after in a group of five chronic schizophrenics receiving chlorpromazine (CPZ), $200 \mathrm{mg}$ t.i.d. for 1 month. These five patients had a mean \pm S.E. plasma TP of $14.3 \pm 1.6 \mu \mathrm{g} / \mathrm{ml}$ while on CPZ and $14.0 \pm 0.7 \mu \mathrm{g} / \mathrm{ml}$ when drug free. Using a paired $t$ test there was no significant difference in plasma levels before and after CPZ. Also when the plasma value for normal subjects was compared to these five, both on and off $\mathrm{CPZ}$, there were no significant differences.

In Fig. 2 and Table 2 are given the mean plasma TP parameters following the load. Compared to a larger group of normals, chronic drug free schizophrenics tended to have a slightly elevated plasma TP but well within the range for normal $(p<0.05)$. After the load the prisoners tended to have a more flattened plasma tolerance curve which was statistically significant $(p<0.05)$. The mean \pm S.E. time of peak TP was approximately $1.2 \pm 0.2 \mathrm{hr}$ 


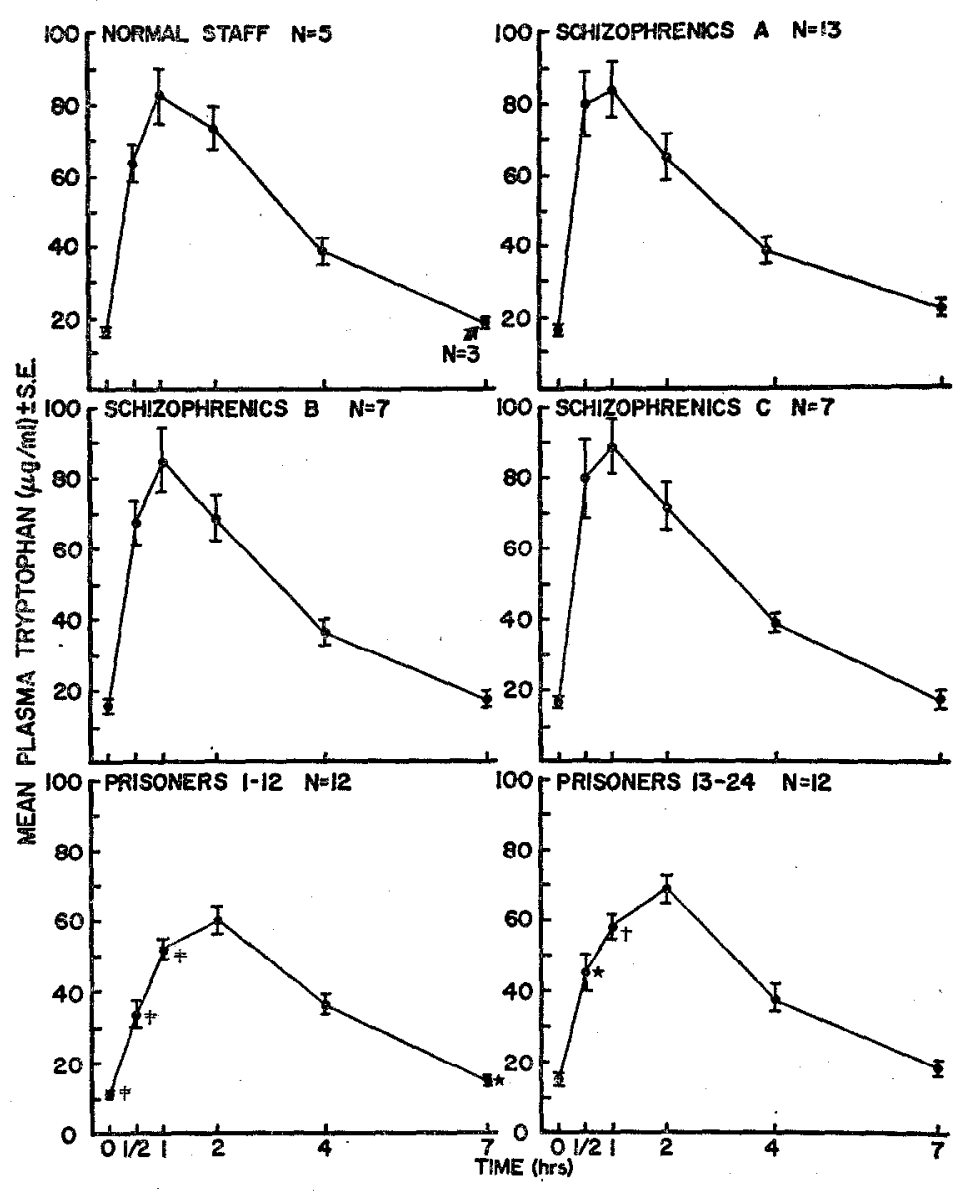

FIG. 1. Mean plasma tryptophan tolerance curves following oral loading ( $32 \mathrm{mg} / \mathrm{kg}$ ). Plasma levels of TP vs time are shown. Note that only the prisoner volunteers showed abnormal tolerance curves. Symbols in this figure are as follows: $N$, number of subjects, Schizophrenics A, $S$-protein helical, B, $S$-protein nonhelical, C, S-protein variable, Prisoners 1-12 and 13-24 were two groups of which the first 12 had their samples drawn $1 \mathrm{hr}$ earlier than the last 12 .

for the normals and peak TP for the chronic schizophrenic and prisoner volunteer groups was not significantly different from control. Although the normal subjects and the chronic schizophrenics did not differ in any other TP parameter, the prisoner volunteers (13-24) showed less of a TP peak, smaller $\Delta T P$ (peak minus fasting) and a smaller area under their TP tolerance curve as measured from $0-1 \mathrm{hr}(p<0.05)$. Further, the prisoners showed a much longer plasma half-life which was statistically significant $(p<0.05)$. Although the use of an oral TP load to measure half-life is of course subject to criticism, nevertheless, the data obtained indicate a mean \pm S.E. plasma half-life of oral TP of $2 \cdot 1 \pm 0 \cdot 2 \mathrm{hr}$ for normals and $2 \cdot 5 \pm 0 \cdot 1 \mathrm{hr}$ for chronic schizophrenic patients. In contrast, prisoner volunteers showed a significantly longer mean \pm S.E. half-life of $2.9 \pm 0.3 \mathrm{hr}(p<0.05)$. 


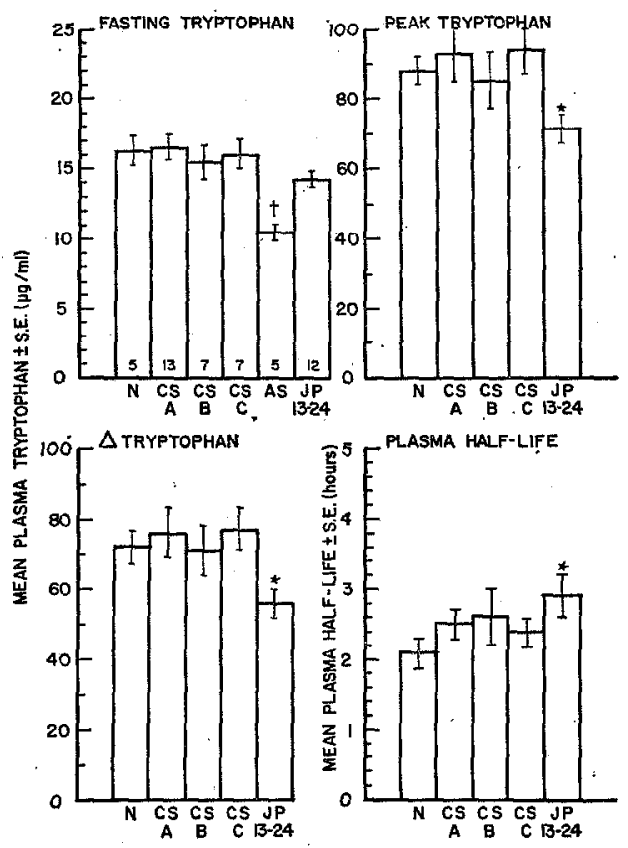

FIG. 2. Bar graph of mean plasma tryptophan concentration after oral loading ( $32 \mathrm{mg} / \mathrm{kg}$ ). Four TP parameters are shown for various groups as indicated. Symbols in this figure are as follows: $N$, normal staff volunteers; CS, chronic schizophrenics, A, B, C as in Fig. 1; JP 13-24, Jackson prisoners. All subjects were run under identical conditions except AS, acute schizophrenics had only the fasting. TP. Note that the acute schizophrenics and the prisoner volunteers differed in their TP parameters from the other groups.

Effects of a standard meal on plasma TP in chronic schizophrenic patients and prisoner volunteers

Chronic schizophrenic patients were subdivided on the basis of presence (group A) or absence (group B) of the $\alpha$ helical $S$-protein, or former presence of the protein (group C). Patients were fasted in the afternoon and evening for $8 \frac{1}{2} \mathrm{hr}$ in which the last meal was lunch at 12:00 noon. The patients had no additional food until after their blood was drawn at $8: 30$ p.m. They were then given a regular meal. At another time the patients as well as the prisoner volunteers were given a standard dinner at 5:30 p.m. and their blood drawn at 8:30 p.m. As can be seen from the data in Table 3 all chronic schizophrenics had a significant elevation in their 8:30 p.m. plasma determined on samples taken $3 \mathrm{hr}$ postprandially compared to the 8:30 p.m. fasting plasma sample. The mean \pm S.E. of the evening fasting sample was $14.4 \pm 0.5$ compared to $19.6 \pm 0.5 \mu \mathrm{g} / \mathrm{ml} 3 \mathrm{hr}$ postprandial. These differences were also significant when the chronic schizophrenics were separated as subgroups A, B and C. Chronic schizophrenics in groups $A$ and $C$ tended to have higher plasma TP than those in group B $(p<0 \cdot 01)$. Prisoner volunteers eating the standard evening meal tended to have less of an elevation in mean plasma TP than the schizophrenic patients. The mean \pm S.E. of 24 prisoner volunteers was $13.6 \pm 0.6$ compared to $19.6 \pm 0.5 \mu \mathrm{g} / \mathrm{ml}$ for the 28 chronic schizophrenics. This difference was highly significant $(p<0.001)$. 
Table 3. Mean plasma tryptophan following a standakd meal in chronic schlzophrenics and PRISONER VOLUNTEERS

Mean \pm S.E. plasma

Tryptophan

$(\mu \mathrm{g} / \mathrm{ml})$

\begin{tabular}{lrcrc}
\hline \multicolumn{1}{c}{ Group } & $N$ & Evening sample fasting & $N$ & Evening sample postprandial \\
\hline Chronic & & & & \\
schizophrenics & 22 & $14 \cdot 4 \pm 0 \cdot 5 \%$ & 28 & $19 \cdot 6 \pm 0.5$ \\
schizophrenics A & 12 & $14 \cdot 0 \pm 0 \cdot 8+$ & 12 & $20 \cdot 8 \pm 0.9 *$ \\
schizophrenics B & 5 & $15 \cdot 1 \pm 1 \cdot 1 *$ & 9 & $17 \cdot 2 \pm 0 \cdot 5$ \\
schizophrenics C & 5 & $14.5 \pm 1 \cdot 0 *$ & 7 & $20 \cdot 4 \pm 0 \cdot 8^{*}$ \\
Prisoner volunteers & & & 24 & $13.6 \pm 0.6 \dagger$ \\
\hline
\end{tabular}

* Group comparison $t$-test $p<0.01$ compared to chronic schizophrenics Group B.

$\dagger$ Group comparison $t$-test $p<0.001$ compared to all chronic schizophrenics.

$\$$ Paired comparison $t$-test $p<0.01$ for those patients common to both fasting and postprandial states.

\section{Plasma TP in nondepressed vs depressed prisoner volunteers}

Prisoncr volunteers were separated into two groups on the basis of their MMPI scores as not depressed vs depressed. Both groups also had personality disorder characteristics as would be expected of prisoners. As illustrated in Fig. 3 and Table 4, there were significant differences in the prisoner volunteers on various TP parameters. The nondepressed prisoners tended to have slightly higher mean \pm S.E. plasma TP in response to a standard meal as well
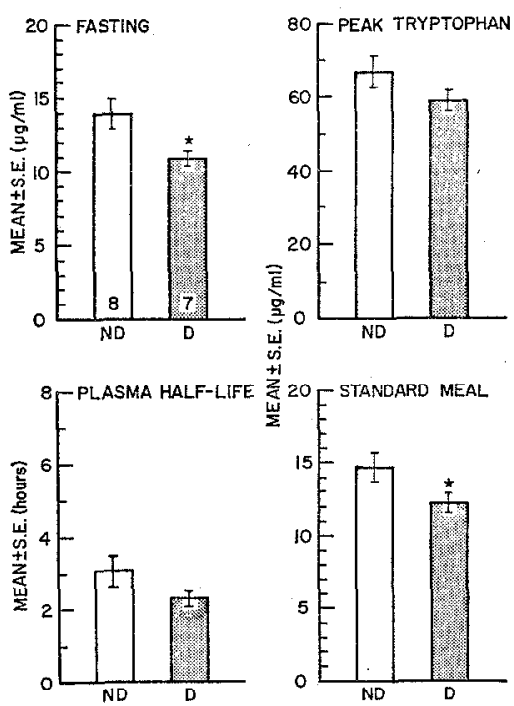

FIG. 3. Mean plasma tryptophan levels in non-depressed vs depressed prisoners. ND, Non-depressed, $D$, depressed prisoners on the basis of their MMPI scores. Both groups showed personality disorders but no psychotic tendencies. Note that the depressed prisoners differ significantly $(p<0.05)$ on two of the four TP parameters shown. 
Table 4. Mean plasma TP parameters following a $32 \mathrm{mg} / \mathrm{kg}$ oral load

\begin{tabular}{|c|c|c|}
\hline \multirow[b]{2}{*}{ Tryptophan parameter } & \multicolumn{2}{|c|}{ Prisoner volunteers } \\
\hline & $\begin{array}{l}\text { Not depressed } \\
\quad(N=8)\end{array}$ & $\begin{array}{l}\text { Depressed } \\
(N=7)\end{array}$ \\
\hline $\begin{array}{l}\text { Standard meal } \\
\mu \mathrm{g} / \mathrm{ml} \\
\text { Fasting }\end{array}$ & $14.7 \pm 0.9$ & $12 \cdot 2 \pm 0 \cdot 7^{*}$ \\
\hline $\begin{aligned} & \mu \mathrm{g} / \mathrm{ml} \\
& \text { Peak TP }\end{aligned}$ & $13 \cdot 9+1 \cdot 0$ & $11 \cdot 1 \pm 0 \cdot 6^{*}$ \\
\hline $\begin{array}{l}\mu \mathrm{g} / \mathrm{ml} \\
\Delta \mathrm{T} \text { (peak minus fasting) }\end{array}$ & $67 \cdot 1+4 \cdot 2$ & $59 \cdot 2 \pm 3 \cdot 3$ \\
\hline $\begin{array}{l}\mu \mathrm{g} / \mathrm{ml} \\
\text { Time of peak }\end{array}$ & $53 \cdot 2 \pm 3 \cdot 7$ & $48 \cdot 1 \pm 3 \cdot 5$ \\
\hline $\begin{array}{l}\mathrm{hr} \\
\text { Slope }(2-4 \mathrm{hr})\end{array}$ & $1 \cdot 9 \pm 0 \cdot 1$ & $1 \cdot 5 \pm 0 \cdot 2$ \\
\hline $\begin{array}{l}\mu \mathrm{g} / \mathrm{ml} / \mathrm{hr} \\
\text { Slope }(4-7 \mathrm{hr})\end{array}$ & $-13 \cdot 6 \pm 2 \cdot 3$ & $-12.8 \pm 0.7$ \\
\hline $\begin{array}{l}\mu \mathrm{g} / \mathrm{ml} / \mathrm{hr} \\
\text { Measured area }(0-1 \mathrm{hr})\end{array}$ & $-7 \cdot 4 \pm 0.4$ & $-4.9 \pm 0.8 *$ \\
\hline $\begin{array}{l}\mu \mathrm{g} \times \mathrm{hr} / \mathrm{ml} \\
\text { Normalized area }(0-1 \mathrm{hr})\end{array}$ & $21 \cdot 8 \pm 3 \cdot 3$ & $28 \cdot 2 \pm 3 \cdot 7$ \\
\hline $\begin{array}{l}\mu \mathrm{g} \times \mathrm{hr} / \mathrm{ml} \\
\text { Measured area }(1-7 \mathrm{hr})\end{array}$ & $39 \cdot 7 \pm 5 \cdot 0$ & $51 \cdot 8 \pm 4 \cdot 0$ \\
\hline $\begin{array}{l}\mu \mathrm{g} \times \mathrm{hr} / \mathrm{ml} \\
\text { Normalized area }(1-7 \mathrm{hr})\end{array}$ & $167 \cdot 7 \pm 13 \cdot 8$ & $138 \cdot 0 \pm 8 \cdot 4$ \\
\hline $\begin{array}{c}\mu \mathrm{g} \times \mathrm{hr} / \mathrm{ml} \\
\text { Measured area }(0-7 \mathrm{hr})\end{array}$ & $314 \cdot 6 \pm 30 \cdot 3$ & $260 \cdot 6 \pm 13 \cdot 4$ \\
\hline $\begin{array}{l}\mu \mathrm{g} \times \mathrm{hr} / \mathrm{ml} \\
\text { Normalized area }(0-7 \mathrm{hr})\end{array}$ & $189 \cdot 5 \pm 14 \cdot 1$ & $166 \cdot 2 \pm 10 \cdot 4$ \\
\hline $\begin{array}{l}\mu \mathrm{g} \times \mathrm{hr} / \mathrm{ml} \\
\text { Plasma half-life }\end{array}$ & $354 \cdot 4 \pm 29 \cdot 4$ & $312 \cdot 3 \pm 11 \cdot 8$ \\
\hline $\mathrm{hr}$ & $3 \cdot 1 \pm 0 \cdot 4$ & $2 \cdot 3 \pm 0 \cdot 2 \dagger$ \\
\hline
\end{tabular}

*As in Table 1.

$\uparrow$ Significant at 0.05 level, one-tailed group comparison $t$-test.

as in the morning fasting state $(p<0.05)$. Eight nondepressed prisoner volunteers had a mean \pm S.E. plasma TP following the standard meal of $14.7 \pm 0.9$ compared to seven depressed prisoner volunteers who had $12.2 \pm 0.7 \mu \mathrm{g} / \mathrm{ml}(p<0.05)$. The same situation was true for the morning fasting state. The nondepressed prisoners had a fasting plasma TP of $13.9 \pm 1.0$ compared to the depressed prisoners who had a TP level of $11.1 \pm 0.6 \mu \mathrm{g} / \mathrm{ml}$. Numbers of prisoners from both the 1-12 vs 13-24 groups were distributed in these two groups such that the difference in a.m. fasting TP between groups was unrelated to a $1 \mathrm{hr}$ difference in blood drawing time. There were no significant differences in peak TP, $\triangle T P$, time of peak TP or the 2-4 hr slope of plasma TP in response to the oral TP load. However, the depressed prisoners had a significantly different TP slope from 4-7 hr. All other parameters were similar except that mean plasma half-life tended to be shorter for the depressed prisoners.

\section{DISCUSSION}

There have been many quantitative studies on metabolites of TP in blood and urine and its regulation by vitamin $B_{6}$ and steroid hormones. ${ }^{28}$ Various investigators have used TP load 
tests in studying epilepsy, ${ }^{29}$ sclcroderma, ${ }^{30}$ and mongolism. ${ }^{31}$ One of the most impressive studies measuring plasma TP tolerance curves after an oral TP load has been that of Yarbro and Anderson $^{32}$ in phenylketonuric patients. These investigators showed a marked disturbance in the absorption peak and disappearance of plasma TP in phenylketonurics compared to normal children. This is presumably because the high phenylalanine levels of phenylketonurics compete with TT for the aromatic amino acid transport systcm.

Price and his associates ${ }^{33}$ have reviewed some evidence for a functional disturbance in the tryptophan-niacin pathway in chronic schizophrenic patients. Kopin ${ }^{34}$ found that the excretion of 5-hydroxyindoleacetic acid was completely normal in chronic schizophrenic

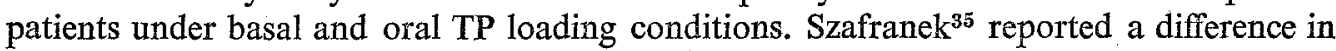
plasma TP in chronic schizophrenic patients when they were on phenothiazine medication. Plasma TP appeared to be elevated using a colorimetric analysis. Inasmuch as it is known that psychotropic drugs alter most free amino acids in the brain, ${ }^{36}$ it seemed crucial to measure plasma TP under non-drug conditions. However, it should be noted that in the present study five chronic schizophrenics showed no difference in fasting plasma TP before or after approximately one month of $600 \mathrm{mg}$ of daily chlorpromazine.

In general, chronic schizophrenic patients free of drugs did not differ significantly from controls in either mean fasting plasma TP or after an oral load. A subdivision of chronic schizophrenic patients with and without $\alpha$ helical $S$-protein of Frohman and Gottlieb ${ }^{\mathbf{2 . 3}}$ did not reveal any significant differences except that those with $\alpha$ helical $S$-protein tended to have a higher plasma TP in response to the standard dinner. However, their TP tolerance curves were normal. We have no explanation for this discrepancy. Obviously there are marked differences between an amino acid load and a complete meal including the time of the day, and differential rates of breakdown, absorption, and utilization of food, etc. A barely significant $(p<0.05)$ increase in mean plasma fasting TP was observed in all of the chronic schizophrenic patients compared to all normals. In contrast, the acute schizophrenic patients showed a lower mean plasma TP than the normals or chronic patients $(p<0.001)$. Although this difference was statistically significant, plasma TP for all patient groups was within the normal range.

Recently, Manowitz and Gilmour et al. ${ }^{37,38}$ reported that acute schizophrenic patients have low plasma TP and normal phenylalanine and tyrosine levels. Because plasma TP was selectively reduced these investigators concluded this could not be due to an inadequate diet although a control for starvation was not included. Our findings in acute schizophrenic patients confirm that plasma TP is reduced. The fact that hospitalization of acute patients causes plasma TP to return to normal can be interpreted either as due to diet or reduced stress.

It has been known for some time that most plasma TP is bound to plasma proteins. ${ }^{39}$ More recently Knott and Curzon ${ }^{40}$ and Gessa et al. ${ }^{41}$ have reexamined this phenomenon in relation to brain TP and 5-HT. Brain TP is highly correlated with the much smaller ultrafilterable fraction of free plasma amino acids. Hence an examination of free vs bound plasma or serum TP in mental disease is of great interest. We are now doing this in chronic schizophrenic patients. ${ }^{42}$ As has been pointed out by Fernstrom and Wurtman, ${ }^{16}$ brain 5-HT content in the rat is dependent on plasma TP under normal fasting or circadian rhythm conditions. While brain 5-HT content increases with a relative increase in plasma TP as can 
occur with a load, after a standard meal brain 5-HT is regulated by the ratio of various plasma neutral amino acids to TP. ${ }^{17}$ This finding is to be expected in view of the fact that various amino acids compete for the same transport system as TP. It is also well known that there is a variation in plasma TP both in the rat $^{16}$ and human ${ }^{43.44}$ depending upon the time of the day. Young et $a .^{45}$ have also studied the effects of TP intake, spacing of meals, and diurnal fluctuations in plasma TP in man. Weller et al. ${ }^{46}$ have reported upon changes in fasting of postprandial amino acids of men fed an adequate or protein free diet.

Our own studies comparing prisoner volunteers 1-12 and 13-24 to controls showed that administering the load $1 \mathrm{hr}$ earlier (6:30-7:00 a.m. for 1-12 compared to 7:30-8:00 a.m. for 13-24) resulted in a highly significant difference in mean fasting and post-load plasma TP. Thus, time of the day as well as diet appear to be critical in the measurement of plasma TP. Depressed prisoners showed a significant decrease in fasting plasma TP and decreased plasma TP response to a standard meal. The 4-7 hr slope of TP disappearance after load was less in the depressed patients, although a reason for this is not obvious at present. The decreased plasma TP may be related to alterations in growth hormone and corticosteroids that have been demonstrated in depression. Lapin and Oxenkrug ${ }^{47}$ have postulated that depressed patients may have a shunting of TP toward the kynurenine pathway due to an increase in liver tryptophan oxygenase activity induced by corticosteroids which are elevated in depression..$^{48}$ On the other hand the response of growth hormone to L-Dopa is reduced in depressed patients. ${ }^{49}$ Growth hormone reduces corticosteroid stimulation of tryptophan oxygenase. ${ }^{50}$ Both of these endocrine alternations in depression would tend to facilitate TP removal from the plasma. While such a hypothesis might account for the decrease in fasting levels of plasma TP in the depressed prisoners in this study, this does not seem to be a universal finding. Coppen ${ }^{51}$ has not observed a significant difference in mean plasma total TP in depressed vs nondepressed patients. Our finding of a decreased slope of TP disappearance in the depressed prisoner volunteers is paradoxical since this would indicate a generally flatter TP tolerance curve in depressed patients. Obviously, this finding must be repeated in other depressed people since a prisoner population has a most complex psychiatric and environmental status.

An important difference between the prisoner volunteers and the other patients studied was the fact that the prisoner study was carried out on a hospital ward while the patients and normals were studied in a laboratory environment. This allowed the prisoners to lie in bed and many of them slept through much of the study even though they were free to walk around. The normal volunteers and the chronic schizophrenics usually sat up and went about their normal activities without the opportunity of lying down. This might account for some of the differences observed.

There were remarkably few side effects following the $32 \mathrm{mg} / \mathrm{kg}$ TP load. Several of the chronic schizophrenics showed symptoms resembling hypoglycemia or hypotension although no significant change in blood pressure was observed. In spite of a 10-fold elevation in plasma TP, no psychic or mental changes were observed such as have been reported with much larger doses of TP in normal volunteers or in patients given TP plus a monoamine oxidase inhibitor. ${ }^{10-12}$

In the present study we had a great deal of difficulty preventing subjects or patients from smoking tobacco cigarettes and drinking coffee. This was overcome in part by allowing the 
subjects to smoke tobacco-free cigarettes and drink decaffeinated coffee. Although Brown et al. ${ }^{22}$ have shown that tobacco smoking has no significant effect on the excretion of TP metabolites in man, the role of coffee drinking on plasma TP has yet to be studied. Dietary deprivations decrease concentrations of some essential serum amino acids in man ${ }^{(46)}$ although much more needs to be known for TP. The prisoner volunteers in general had a much poorer dict comparcd to the high protein meals available to the chronic schizophrenic patients. Thus, it may be that some of the changes observed in mean fasting TP might be explained on a nutritional basis.

What is dramatically clear is that there are no marked differences in the way TP is absorbed or handled in the blood stream of chronic schizophrenic patients. The finding of a difference in the plasma TP tolerance curve of depressed vs nondepressed prisoners must be regarded as extremely preliminary since the entire prisoner group showed abnormalities. Additional studies using oral TP loads in acute schizophrenics and depressed patients are clearly warranted. However, the role of nutritional and endocrine abnormalities will have to be carefully ascertained and controlled.

\section{SUMMARY}

Plasma TP was determined fluorometrically in four groups of males: (1) normal controls (2) chronic schizophrenics (3) acute schizophrenics and (4) prison volunteers with personality disorders with and without symptoms of depression. To control for circadian rhythm all subjects were fasted overnight or in the afternoon and evening prior to withdrawal of venous blood. Fasting a.m. or p.m. plasma TP was within the range of normal for all groups. However, the acute schizophrenics and prison volunteers had lower plasma TP than the normal controls and chronic schizophrenics $(p<0.01)$. Plasma TP was determined before an 8:00 a.m. TP load and at $\frac{1}{2}, 1,2,4$ and $7 \mathrm{hr}$ after ingestion. A plasma tolerance curve was obtained with a peak at 1-2 hr which returned almost to normal at $7 \mathrm{hr}$. Various TP parameters were measured including fasting, peak, maximal change in TP, time of peak, slope 2-4 and 4-7 hr, measured and normalized areas under the plasma tolerance curve, and plasma half-life. Almost no significant differences were found between normal controls and the chronic schizophrenics. Although all prison volunteers showed a markedly different TP tolerance curve from either the normal controls or chronic schizophrenics, depressed prisoners had a significantly lower and flatter curve. It appears that TP is well absorbed from the gastrointestinal tract and its plasma half-life is normal in chronic schizophrenics. Further studies in acute schizophrenics and depressed patients are indicated.

Acknowledgements-We thank Dr. Jacques S. Gottlieb, Director of the Lafayette Clinic, for making this study possible. The attendant and nursing staff, especially Mrs. Phyllis Thrasher, and the dietician, Mrs. Armesia H. Lloyd, contributed greatly to the success of this study. The authors would also like to acknowledge Dr. Charles E. Frohman and his associates in the Biochemistry Department and the Clinical Laboratory, especially in the classification of the chronic schizophrenics on the basis of the plasma $\alpha-2$-globulin. Miss Joanne Bowers and Mr. Nolan Shaw assisted in some of the tryptophan assays: Drs. Hodges and Smith and $\mathrm{Mr}$. Wood of Parke Davis made available the prison volunteers in their facility at the State Prison of Southern Michigan at Jackson. Dr. Phillip Rennick, Ms. Peggy Heffner and Dr. Peter Stenn were responsible for subdividing the prisoner population into different symptom clusters. The MMPI's were scored by Mrs. Novella Kirby. Dr. James Grisell, Mr. George Hovey and their associates in the Computing Laboratory and Miss Debra Domino were most helpful in the statistical analysis of the data. Mr. Patel of the University of Michigan Hospital Pharmacy prepared the L-tryptophan and helped file our 
IND 8851 for this study. Mr. Kenneth Loncharich gave many helpful suggestions during the preparation of the manuscript.

\section{REFERENCES}

1. Himwich, H. E., Kety, S. S., Smythies, J. R. (Editors) Amines and Schizophrenia. Pergamon Press, Oxford, 1967.

2. Frohman, C. E. Biochemical mechanisms, In: Lafayette Clinic Studies on Schizophrenia, Tourney, G. and GotTlieb, J. S. (Editors). Wayne State University Press, Detroit, 1971.

3. GotTlies, J. S., Frohman, C. E. and Harmison, C. R. Schizophrenia-new concepts. South Med. J. 64, 743, 1971.

4. Hтмшісн, H. E. Biochemistry, Schizophrenia and Affective lllness. Williams \& Wilkins, Baltimore, 1971.

5. Narastmhachari, N., Plaut, J. M. and Himwich, H. E. Indolethylamine- $N$-methyltransferase in serum samples of schizophrenics and normal controls. Life Sci. II, 11, 221, 1972.

6. Narastmhachart, N, and Himwich, H. E. The determination of bufotenin in urine of schizophrenic patients and normal controls. J. Psychiat. Res. 9, 113, 1972.

7. SHAw, D. M., Camps, F. E. and Eccleston, E. G. 5-Hydroxytryptamine in the hind-brain of depressive suicides. Br. J. Psychiat. 113, 1407, 1967.

8. Bourne, H. R., Bunney, W. E., Jr., Colburn, R. W., Davis, J. N., Shaw, D. M. and Coppen, A. J. Noradrenaline, 5-hydroxytryptamine, and 5-hydroxyindoleacetic acid in hindbrains of suicidal patients. Lancet 2, 805, 1968.

9. Coppen, A. Biogenic amines and affective disorders. Adv. Ment. Sci. 4, 123, 1971.

10. OAtes, J. A. and SJoERdsma, A. Neurologic effects of tryptophan in patients receiving a monoamine oxidase inhibitor. Neurol. (Minneapolis) 10, 1076, 1960.

11. Pollin, W., CArdon, P. V., Jr. and KeTY, S. S. Effects of amino acid feedings in schizophrenic patients treated with iproniazid. Science 133, 104, 1961.

12. Sмгтн, B. and Prockop, D. J. Central nervous system effects of ingestion of L-tryptophan by normal subjects. New Engl. J. Med. 267, 1338, 1962.

13. Alexander, F., CurTis, G. C., Sprince, H. and Crosley, A. P., Jr. L-methionine and L-tryptophan feedings in non-psychotic and schizophrenic patients with and without tranylcypromine. $J$. Nerv. Ment. Dis. 137, 135, 1963.

14. Coppen, A., Shaw, D. M., Herzberg, B. and Maggs, R. Tryptophan in the treatment of depression. Lancet 2, 1178, 1967.

15. CopPen, A. and Noguera, R. L-tryptophan in depression. Lancet 1, 1111, 1970.

16. FERNSTROM, J. D. and WURTMAN, R. J. Brain serotonin content: physiological dependence on plasma tryptophan levels. Science 173, 149, 1971.

17. Fernstrom, J. D. and Wurtman, R. J. Brain serotonin content: physiological regulation by plasma neutral amino acids. Science 178, 414, 1972.

18. Dahlstrom, W. G. and WeLsh, G. S. An MMPI Handbook: A Guide to Use in Clinical Practice and Research. The University of Minnesota Press, Minneapolis, 1960.

19. Bowes, A. deP. and Church, C. F. Food Values of Portions Commonly Used. Lippincott, Philadelphia, 1937.

20. DenckiA, W. D. and Dewey, H. K. The determination of tryptophan in plasma, liver and urine. J. Lab. Clin. Med. 69, 160, 1967.

21. Williams, J. B. Statistical Analysis. Olivetti Underwood, Michigan, 1969.

22. Snedecor, G. W. Statistical Methods. Iowa State University Press, Ames, Iowa, 1956.

23. Dirm, K. (Ed.) Documenta Geigy (6th ed.), p. 557. Geigy Pharmaceuticals, New York, 1962.

24. ADIBI, S. A. Influence of dietary deprivations on plasma concentration of free amino acids of man J. appl. Physiol. 25, 52, 1968.

25. PERrY, T. L. and HANSEN, S. Technical pitfalls leading to errors in the quantitation of plasma amino acids. Clin. Chim. Acta. 25, 53, 1969.

26. GrbBs, C. C. J., SAunders, S. J. and Sweeney, G. D. Quantitative estimation of tryptophan in plasma and urine using thin-layer chromatography (TLC) and induced fuorescence. Clin. Chim. Acta 17, $317,1967$.

27. Specialized Diagnostic Laboratory Tests. Bio-Science Laboratorics, California, 1971.

28. BRown, R. R. Biochemistry and pathology of tryptophan metabolism and its regulation by amino acids, vitamin $\mathrm{B}_{6}$ and steroid hormones. Am. J. Clin. Nutr. 24, 653, 1971.

29. Hagberg, B., Hamfelt, A. and Hansson, O. Tryptophan load tests and pyridoxal-5-phosphate levels in epileptic children-I. Cryptogenic epilepsy. Acta paediat. scand. 55, 371, 1966. 
30. Hankes, L. V., Brown, R. R., Leklem, J., Schmakler, M. and Jesseph, Y. Metabolism of C14 labeled enantiomers of tryptophan, kynurenine and hydroxykynurenine in humans with scleroderma. $J$. Invest. Derm. 58, 85, 1972.

31. O'Brien, D. and GrosheK, A. The abnormality of tryptophane metabolism in children with monogolism Archs Dis. Childh. 37, 17, 1962.

32. YARBro, M. T. and ANDERson, J. A. L-tryptophan metabolism in phenylketonuria. J. Pediat. 68, 895, 1966.

33. Price, J. M., Brown, R. R. and Yess, N. Testing the functional capacity of the tryptophan-niacin pathway in man by analysis of urinary metabolites, In: Advances in Metabolic Disorders 2, LEVINE, R. and LufT, R. (Editors), pp. 159-225, Academic Press, New York, 1965.

34. KopIN, I. J. Tryptophan loading and excretion of 5-hydroxyindoleacetic acid in normal and schizophrenic subjects. Science 129, 835, 1959.

35. SzafraneK, J. Tryptofan w surowicy krwi chorych na schizofrenie. Psychiat. Pol. II, 259, 1968.

36. TallaN, H. H. Free amino acids in brain after administration of imipramine, chlorpromazine and other psychotropic drugs, In: Amino Acid Pools, Holden, J. T. (Editor). pp. 465-470. American Elsevier, New York, 1962.

37. Manowitz, P., Gilmour, D. G. and Racevskis, J. Low plasma levels in recently hospitalized schizophrenics. Biol. Psychiat. 6, 109, 1973.

38. Gilmour, D. G., Manowitz, P., Frosch, W. A. and Shopsin, B. Association of plasma tryptophan levels with clinical change in female schizophrenic patients. Biol. Psychiat. 6, 119, 1973.

39. MCMenamy, R. H., Lund, C. C. and ONCLEY, J. L. Unbound amino acid concentrations in human blood plasmas. J. Clin. Invest. 36, 1672, 1957.

40. KNott, P. J. and Curzon, G. Free tryptophan in plasma and brain tryptophan metabolism. Nature 239, 452, 1972.

41. Gessa, G. L., Biggio, G. and Tagliamonte, A. Brain serotonin turnover; dependence on free tryptophan concentration in plasma. Fedn. Proc. 31, 2168, 1972.

42. Domino, E. F. and KRAuSE, R. R. Free and bound serum tryptophan in drug free normal controls and chronic schizophrenic patients. Biol. Psychiat., 8, 265, 1974,

43. Rapoport, M. I. and BeISEL, W. R. Circadian periodicity of tryptophan metabolism. J. Clin. Invest. 47, 934, 1968

44. Wurtman, R. J., Rose, C. M., Chou, C. and Larin, E. F. Daily rhythms in the concentrations of various amino acids in human plasma. New Engl. J. Med. 279, 171, 1968.

45. Young, V. R., Hussein, M. A., Murray, E. and Scrmshaw, N. S. Tryptophan intake, spacing of meals and diurnal fluctuations of plasma tryptophan in men. Am. J. Clin. Nutr. 22, 1563, 1969.

46. Weller, L. A., Margen, S. and Calloway, D. H. Variation in fasting and postprandial amino acids of men fed adequate or protein-free diets. Am. J. Clin. Nutr. 22, 1577, 1969.

47. LAPIN, I. P. and OXENKRUG, G. F. Intensification of the central serotonergic processes as a possible determinant of the thymoleptic effect. Lancet $1,132,1969$.

48. Weil-MALherbe, H. and SzARA, S. I. The Biochemistry of Functional and Experimental Psychoses. pp. 87-89. Thomas, Springfield, 1971.

49. Sachar, E. J., Musimush, G., Perlow, M., Weitzman, E. D. and Sassin, J. Growth hormone responses to L-Dopa in depressed patients. Science 178, 1304, 1972.

50. Korner, A. Growth hormone and tryptophan oxygenase activity. J. Clin. Nutr. 24, 712, 1971.

51. CoPPEN, A. Personal communication, 1972.

52. Brown, R. R., Price, J. M., Burney, S. W. and Friedell, G. H. Lack of effect of smoking on the excretion of tryptophan metabolites by man. Cancer Res. 30, 611, 1970. 